\title{
CHROMOSOME NUMBERS OF SOME NEPALESE FLORA
}

\author{
BUDDHA LAXMI VAIDYA ${ }^{1}$ AND LAXMI MANANDHAR ${ }^{1} \bowtie$
}

${ }^{1}$ Botany Instruction Committee,Tri-chandra Multiple Campus, Tribhuvan University, Kathmandu, Nepal

cyberword427370@gmail

\section{ABSTRACT}

Previous and present chromosome counts of 10 Nepalese taxa within 7 families viz. Amaryllidaceae, Asteraceae, Caricaceae, Leguminosae, Nyctaginaceae, Passifloraceae and Scrophulariaceae are reported here. Diploid or haploid chromosome numbers of the taxa collected from the local gardens of Kathmandu are n=15 in Agapanthus africanus (L.) Hoffmanns (Amaryllidaceae); 2n=48+3B in Allium tuberosum Rottler ex Spreng. (Amaryllidaceae); 2n=18 in Artemisia indica Willd. (Asteraceae); $2 n=27$ in Carica papaya L. (Caricaceae); 2n=16 in Cicer arietinum L., 2n=14, 21 in Pisum sativum L., 2n=12 in Vicia faba L. (Leguminosae); 2n=28 in Bougainvillea glabra Choisy (Nyctaginaceae); $2 n=18$ in Passiflora edulis Sims. (Passifloraceae) and 2n= 34 in Bacopa monnieri (L.) Pennel (Scrophulariaceae) in the present research. Of these, the chromosome count of Bougainvillea glabra in this research is perhaps the new report. The reports of chromosome number in Artemisia indica, Carica papaya and Bacopa monnieri in the present investigation are confirmed to be different from the previously reported numbers for these taxa. The chromosome number of Agapanthus africanus, Allium tuberosum, Cicer arietinum, Passiflora edulis, Pisum sativum, Vicia faba in the present research tally with the previous reports. The present counts in Bacopa monnieri, Carica papaya and Passiflora edulis are new records for Nepal.

Keywords: Nepalese flora, genetic diversity, chromosome counts, mitosis

\section{INTRODUCTION}

Nepal occupies the central part of the highest Himalayas. Its flora is exceptionally rich. The flora has been noted as a prestigious heritage in the world. The country is known for its wide range of habitats from the plains to the mountains, with elevation varying from $125 \mathrm{~ms}$ to more than $8839 \mathrm{msl}$ within as less as $4^{\circ}$ width of latitude. The country occupies only $0.1 \%$ of the total land of the earth, however it contains as large as over 7, 000 diverse floral vegetation within ca. 200 families (Manandhar et al., 2010; 2011).

In the eastern parts of the country Sino-Japanese flora are dominant whereas in its western parts the Mediterranean elements are more dominant. The southern Terai region possesses north Indian elements, while in the northern Trans-Himalayan arid zone, the vegetation is similar to that of Tibet. The country can therefore be regarded as an area of transition or the merging point of the flora (Nepal Biodiversity Strategy, 2002). It is also noteworthy that the Himalayas and immediate adjacent areas contain 1223 plant species of which $975(79.7 \%)$ are endemic or limited to the adjacent areas (Ohba, 1997). This diversity in flora harbors within it a huge genetic diversity.

Kumar \& Subramanian (1986) have estimated that the risk of extinction of the existing floral 
diversity in the near future, due to global climate change and habitat loss, is as high as 25 percent. The cytologically known flowering plants are only about $25 \%$ of 2, 50,000 on earth and the Himalayan flora are much less investigated in the cytological field (Wakabayashi, 1988; Dhar, 2002).

The literature (Hara \& Williams, 1979; Hara et al., 1982; Press et al., 2000; Rajbhandari, 2002-2003) indicates that the genera represented in Nepal are 5 in Amaryllidaceae, 111 in Asteraceae, 1 in Caricaceae, 80 in Leguminosae, 3 in Nyctaginaceae, 1 in Passifloraceae and 37 in Scrophulariaceae. The presently researched genera of the above mentioned families may be a valuable addition document to give recognition of the plant genetic heritage resources of the country to scientific world.

\section{MATERIALS AND METHODS}

The somatic chromosome counts in the present investigation were obtained from the root tips (mitosis). The haploid count was done from the microsporogenesis in flower buds (meiosis). The mitotic studies were made from fixed excised healthy root tip cells. To ensure full turgidity, plants were sufficiently watered two hours before the excision of the root tips for pretreatment. The root tips were taken in between 9.00 AM and 11.00 AM. The root tips were cleaned with the help of a fine camel hair brush before pretreatment. The materials were pretreated in aqueous solution of super saturated solution of para-dichlorobenzine for $3 \mathrm{hrs}$ at room temperature before fixing them. The fixative used for roots as well as floral buds was acetic alcohol (glacial acetic acid and ethyl alcohol in 1:3 ratios). The root tip cells were made soft by treating root tips with $1 \mathrm{~N} \mathrm{HCl}$ for about 3 hours (Cota \& Philbrick, 1994).

The terminology of Sakya (1999) was used for chromosome size: small $<1 \mu \mathrm{m}$., medium 1 to $<2.5 \mu \mathrm{m}$. and large above $2.5 \mu \mathrm{m}$.

The meiotic behaviors of pollen mother cells were observed from appropriate anthers of fixed and preserved flower buds. The desired stages of both mitosis and meiosis were photographed under the microscope with 1000 magnifications.

At least five slides were observed to confirm the results of both mitosis and meiosis. Best slides were made permanent by using acetic acid n-butyl alcohol series of three grades viz. the frist grade was of acetic acid and $n$ - butyl alcohol solution in 1: 1 ratio, in the second grade acetic acid was 1 and n- butyl alcohol was 3 in ratio and the third grade was of absolute n- butyl alcohol (Celarier, 1956).

\section{RESULTS}

TABLE 1. List of voucher number (V. N.) of the presently studied taxa. Place of collection and chromosome number. 


\begin{tabular}{|l|l|l|l|}
\hline VN & Taxa & $\begin{array}{l}\text { Place of collection } \\
(\mathbf{m s l})\end{array}$ & $\begin{array}{l}\text { Chromosome } \\
\text { number }\end{array}$ \\
\hline 54 & Agapanthus africanus (L.) Hoffmanns & Kuleswor, 1250 & $\mathrm{n}=15$ \\
\hline 53 & $\begin{array}{l}\text { Allium tuberosum Rottler ex } \\
\text { Spreng. }\end{array}$ & Kuleswor, 1250 & $2 \mathrm{n}=48+3 \mathrm{~B}$ \\
\hline 112 & Artemisia indica Willd. & Swontha, Lalitpur, 1250 & $2 \mathrm{n}=18$ \\
\hline 302 & Bacopa monnieri (L.) Pennel & Kuleswor, 1250 & $2 \mathrm{n}=34$ \\
\hline 303 & Bougainvillea glabra Choisy & Kuleswor, 1250 & $2 \mathrm{n}=28$ \\
\hline 304 & Carica papaya L. & Kuleswor, 1250 & $2 \mathrm{n}=27$ \\
\hline 120 & Cicer arietinum L. & Lalitpur, 1250 & $2 \mathrm{n}=16$ \\
\hline 305 & Passiflora edulis Sims & Lalitpur, 1250 & $2 \mathrm{n}=18$ \\
\hline 121 & Pisum sativum L. & Lalitpur, 1250 & $2 \mathrm{n}=14,21$ \\
\hline 122 & Vicia faba L. & Kuleswor, 1250 & $2 \mathrm{n}=12$ \\
\hline
\end{tabular}

Countable metaphase photographs of the presently researched taxa are given in fig. 1-12. The reports of present and previous counts for the presently studied taxa are in table 2 .

\section{Amaryllidaceae}

Agapanthus africanus (L.) Hoffmanns. . (V. N. 54), n=15

Both rod and ring bivalents are seen during diakinesis (fig. 1 \& 2). Different phases in meiotic divisions have revealed both normal and irregular stages. Irregularities like chromatin bridges at anaphase I, unequal distribution of chromosomes at telophase I, telophase II and cytomixis between cells were evidenced occasionally. Pentad were noted occasionally.

Allium tuberosum Rottler ex Spreng. (V. N. 53), 2n=48+3B

Mitotic divisions encountered 48 symmetrical as well as asymmetrical graded types of chromosomes (fig. 3). All the chromosomes with centromere at median, sub-median and subterminal regions are large sized. Individuals with a few Bs are evidenced frequently. Abnormal separations of chromosomes are evidenced during telophase in some cases.

\section{Asteraceae}

Artemisia indica Willd. (V. N. 112), 2n=18

Mitotic divisions comprise 18 chromosomes with centromeres at median and sub-median regions (fig. 4). All the chromosomes are large sized.

\section{Caricaceae}

Carica papaya L. (V. N. 304), 2n=27

Mitotic division evidenced 27 chromosomes mostly having centromere at median and submedian regions (fig. 7), but a few of them were sub-terminal ones. Most of the chromosomes were large sized. 


\section{Leguminosae}

Cicer arietinum L. (V. N. 120), 2n=16

Mitotic divisions revealed 16 chromosomes mostly with centromeres at median and sub-median regions (fig. 8). All the chromosomes were large sized.

Pisum sativum L. (V. N. 121), 2n=14, 21

Fourteen chromosomes having centromere at median and sub-median encountered frequently (fig. 10), but triploid individuals with graded chromosomes having centromere at median, submedian and sub-terminal regions were also observed occasionally (fig. 11).

Vicia faba L. (V. N. 122), 2n=12

Twelve large and graded chromosomes with centromere at median, sub-median and subterminal regions were evidenced during countable metaphase. A few B-chromosomes were encountered occasionally (fig. 12).

\section{Nyctaginaceae}

Bougainvillea glabra Choisy (V. N. 303), $2 n=28$

All 28 chromosomes revealed centromere at median and sub-median regions. The chromosomes were all large sized (fig. 6).

\section{Passifloraceae}

Passiflora edulis Sims (V. N.305), $2 \mathrm{n}=18$

Mitotic metaphase encountered 18 chromosomes. All the chromosomes were with centromere at median and sub-median regions (fig. 9).

\section{Scrophulariaceae}

Bacopa monnieri (L.) Pennel (V. N. 302), 2n=34

Mitotic division encountered 34 chromosomes with centromere at median and sub-median regions (fig. 5). The chromosomes were small, medium as well as large sized. The chromosomes were of graded types with centromere at median, sub-median and sub-terminal regions.

B
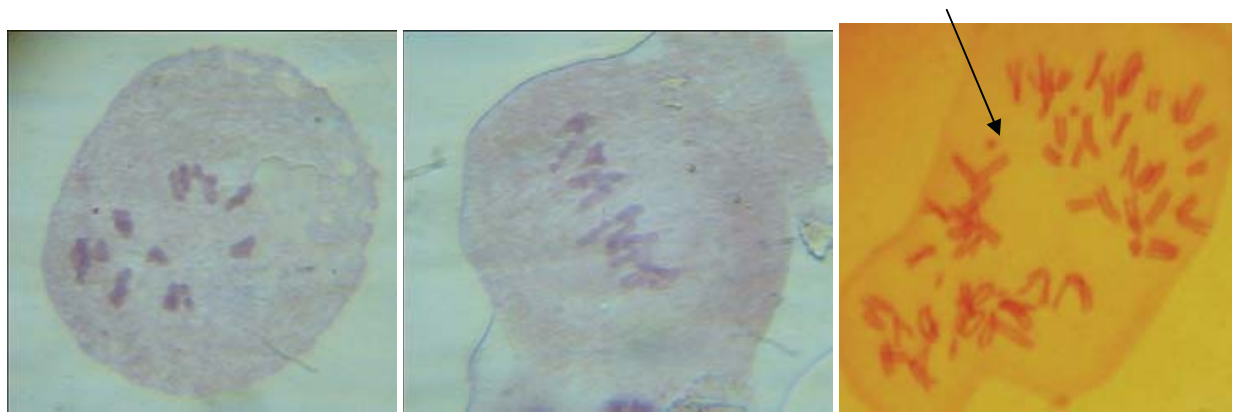

FIG. 1.

FIG. 2.

FIG. 3. 


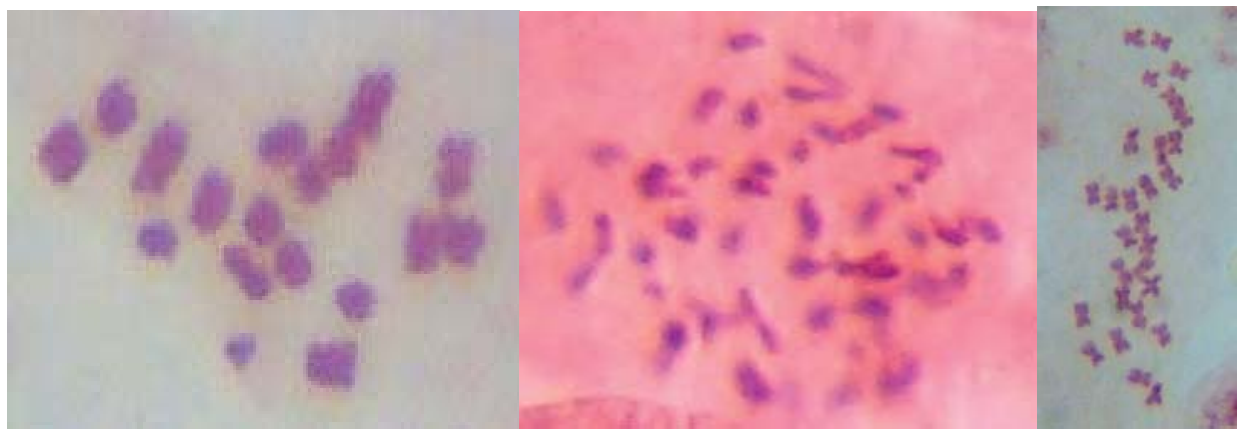

FIG. 4.

FIG. 5.

FIG. 6.

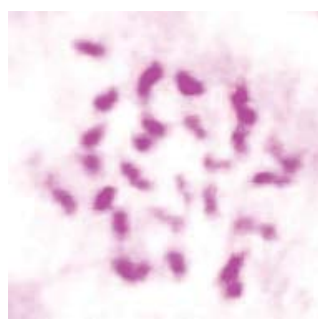

FIG. 7.

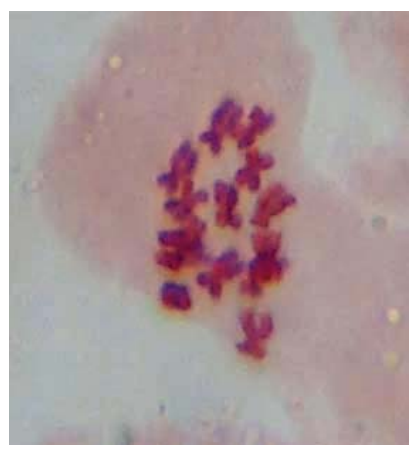

FIG. 10

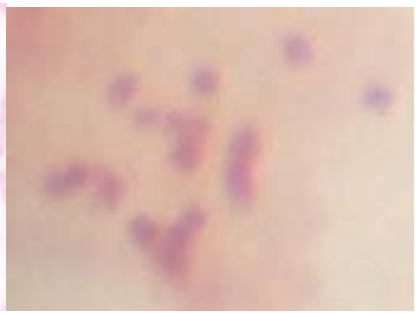

FIG. 8.

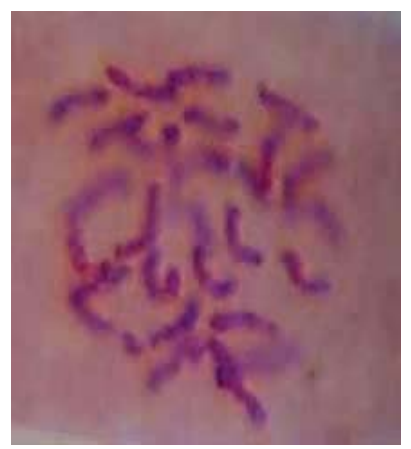

FIG. 11

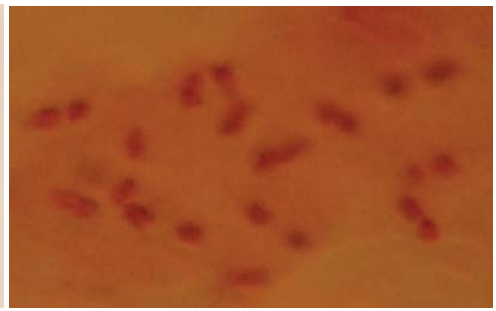

FIG. 9.

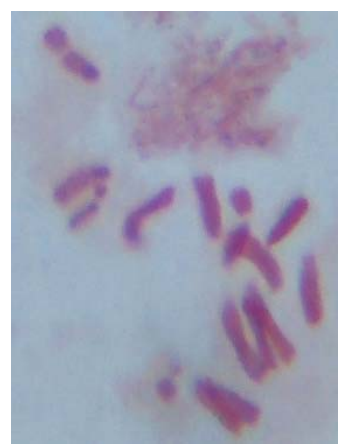

FIG.12

\section{Legends for Figures}

FIG. 1. Agapanthus africanus (L.) Hoffmanns. n=15. Fig. 2. Agapanthus africanus (L.) Hoffmanns. (meiotic bivalents in a row) Fig. 3. Allium tuberosum Rottler ex Spreng. $2 n=48+3 B$. Fig. 4. Artemisia indica Willd. $2 n=18$. Fig. 5. Bacopa monnieri (L.) Pennel 2n=34. Fig. 6. Bougainvillea glabra Choisy 2n=28. Fig. 7. Carica papaya L. 2n=27. Fig. 8. Cicer arietinum L. 2n=16. Fig. 9. Passiflora edulis Sims 2n=18. Fig. 10. Pisum sativum L. 2n=14. Fig. 11. Pisum sativum L. 2n=21. Fig.12. Vicia faba L. $2 n=12$. 


\section{DISCUSSION}

Agapanthus africanus has been reported with chromosome number $2 \mathrm{n}=30$ (Prajapati, 2000; Sakya et al., 2001). This taxa is with $n=15$ in the present investigation. It can be suggested that the taxa maybe having basic number $x=15$.

Different species of Allium have been reported with the haploid number $n=8$ (c. $82 \%$ Federov, 1969). It can be suggested that this genus is with the basic number $x=8$ and may be unibasic (Manandhar et al., 2011). A. tuberosum is reported with 2n=32, 48+3B (Banerjee, 1980; Xu et al., 1985; Nanuscyan \& Polyakov, 1989; Li, 1989; Ohi, 1990; Shang et al., 1997; Zhang, 1998; Yan et al.,1999; Talukder \& Sen, 2000, Ohri \& Pistrick, 2001; Manandhar et al., 2011). Previous reports support that $A$. tuberosum is a tetraploid one with the basic number $\mathrm{x}=8$ in the taxa. However $A$. tuberosum has also been reported with the irregular numbers viz. $n=8 \mathrm{IV}$ - 32I, 2n=9, 11, 24, 32, 31-33, n=8-10, 8-14, 31 (irr), 32 (irr)etc 2n=31, 32, 33, 62 (Seo, 1977; Gohil \& Koul, 1983; Roy, 1980), $n=32,2 n=64$ Kojima et al. (1991). 2n=24 Huang et al. (1985). This shows that polyploids and aneuploids have been occurring frequently in this taxa. It may be suggested that $2 n=32$ and $2 n=64$ are tetraploid and hexaploid individuals respectfully, where as $2 n=24$ should be triploid. In the present report $2 n=48$ may be due to duplication of chromosomes in triploid individuals.

According to Torrel et al. (2001) the basic number for the genus Artemisia are $\mathrm{x}=8$ or 9 and plolyploidy has played significant role in the genus during evolution. Chromosome numbers for Artemisia indica are $2 \mathrm{n}=34$ (Joshi \& Joshi, 2001) and 2n=32 (Manandhar et al., 2011; Karna Mallick et al., 2011) in the previous reports. Present research with $2 n=18$ suggests that the basic number for this taxa may be $n=9$. The previously reported individuals may be due to the loss of a pair or two pairs of chromosomes in tetraploid individuals with basic number $x=9$ or may be due to the duplication of a pair of chromosome $(2 n-34)$ with the basic number $x=8$.

Joshi \& Ranjekar (1982) and Chen (1993) have reported 2n=18 in Carica papaya whereas Fernández Casas (1981) has confirmed $n=18$ in this taxa. It indicates that haploid number $n=18$ in this taxa may be of tetraploid individual. The previous report $2 n=18$ should be a diploid one. The presently counted number $2 n=27$ maybe of triploid one.

Perusal of literature (Bairiganjan \& Patnaik, 1989; Yan et al., 1989; Mannan et al., 1991; Venora et al., 1995; Nazarova, 1997; Kabir \& Singh, 1991; Ahmad, 1993; Jahan et al., 1994; Ahmad \& Chen, 2000; Manandhar, 2012) has suggested that Cicer arietinum is with the basic number $x=8$. The present research with $2 n=16$ also suggests that this taxa is unibasic.

Several authors (Marks \& Davies, 1979; Mercy Kutty \& Kumar, 1983; Bairiganjan \& Patnaik, 1989) have reported $n=7,2 n=14$ in Pisum sativum. Present report $2 n=14,21$ confirms that the taxa contains both diploid and triploid individuals.

Present report for Vicia faba $2 n=12$ tallies with the perusal of literature (Langer \& Koul, 1982; Rost, 1982; Tanaka \& Ohta, 1982; Anis et al., 1998 ; Zhang, 1998; Kamel, 1999; Koul et al., 1999). The reports $n=6$ by Kesavacharyulu et al. (1982) and Jahan et al. (1994) have indicated that this taxa is with the basic number $x=6$. The irregular number $n=4,5,6,7$ reported by Wang \& Zheng (1985) maybe due to disploidy. 
Bougainvillea glabra reported here is with $2 n=28$. This is perhaps the first report for this taxa. Passiflora edulis has been reported with $2 n=18$ (Guerra, 1986). There is no haploid number report for this taxa. Present report $2 n=18$ maybe a diploid individual that tallies with the earlier report.

There is no haploid number report for the taxa Bacopa monnieri. This taxa has been reported with $2 n=68$ (Chandran \& Bhavanandan, 1981) previously. Present report $2 n=34$ suggests that basic number for the taxa may be $x=17$. The previously reported individual of this taxa may be a tetraploid one.

With the exception of the genus Artemisia, all the presently studied taxa may be of unibasic nature. It is noteworthy that all the investigated genera, in this research, are with some kind of polyploids. Polyploidy is considered to be one of the characteristics of advancement in the process of evolution and such cases lead to speciation.

TABLE 2. Present and previous chromosome counts for the presently studied taxa.

\begin{tabular}{|c|c|c|c|}
\hline Taxa & $\begin{array}{l}\text { Chromosome } \\
\text { count }\end{array}$ & Author and year & $\begin{array}{l}\text { Distribution } \\
\text { (msl) }\end{array}$ \\
\hline $\begin{array}{l}\text { Agapanthus africanus } \\
\text { (L.) Hoffmanns. }\end{array}$ & $2 n=30$ & Prajapati (2000) & $\begin{array}{l}\text { Botany } \\
\text { garden, } \\
\text { Kirtipur, } 1300\end{array}$ \\
\hline $\begin{array}{l}\text { A. africanus (L.) } \\
\text { Hoffmanns. }\end{array}$ & $2 n=30$ & Sakya et al. (2001) & $\begin{array}{l}\text { Botany } \\
\text { garden, } \\
\text { Kirtipur, } 1300\end{array}$ \\
\hline $\begin{array}{l}\text { A. africanus } \\
\text { (L.) Hoffmanns. }\end{array}$ & $n=15$ & Present report & $\begin{array}{l}\text { Kuleswor, } \\
1250\end{array}$ \\
\hline $\begin{array}{l}\text { Allium tuberosum } \\
\text { Rottler ex } \\
\text { Spreng. }\end{array}$ & $2 n=32,48+3 B$ & $\begin{array}{l}\text { Banerjee (1980), Xu et al. } \\
\text { (1985), Nanuscyan \& } \\
\text { Polyakov (1989) Li (1989), } \\
\text { Ohi (1990), Shang et al. } \\
\text { (1997), Zhang (1998), } \\
\text { Yan et al. (1999), Talukder } \\
\text { \& Sen (2000), Ohri \& } \\
\text { Pistrick ( 2001) }\end{array}$ & $\begin{array}{l}\text { Cultivated, } \\
1200\end{array}$ \\
\hline $\begin{array}{l}\text { A. tuberosum Rottler ex } \\
\text { Spreng. }\end{array}$ & $n=32 I I, 2 n=64$ & Kojima et al. (1991) & $\begin{array}{l}\text { Cultivated, } \\
1200\end{array}$ \\
\hline $\begin{array}{l}\text { A. tuberosum Rottler ex } \\
\text { Spreng. }\end{array}$ & $2 n=24$ & Huang et al. (1985) & $\begin{array}{l}\text { Cultivated, } \\
1200\end{array}$ \\
\hline $\begin{array}{l}\text { A. tuberosum Rottler ex } \\
\text { Spreng. }\end{array}$ & $n=8,2 n=32$ & Li et al. (1985) & $\begin{array}{l}\text { Cultivated, } \\
1200\end{array}$ \\
\hline
\end{tabular}




\begin{tabular}{|c|c|c|c|}
\hline $\begin{array}{l}\text { A. tuberosum Rottler ex } \\
\text { Spreng. }\end{array}$ & $\begin{array}{l}n=4 I V+8 I, 2 n= \\
32\end{array}$ & Rao et al. (1992) & $\begin{array}{l}\text { Cultivated, } \\
1200\end{array}$ \\
\hline $\begin{array}{l}\text { A. tuberosum Rottler ex } \\
\text { Spreng. }\end{array}$ & $\begin{array}{l}n=8-10,8-14, \\
31 \text { (irr), 32(irr) } \\
\text { Etc, } 2 n=31,32, \\
33,62\end{array}$ & Seo (1977) & $\begin{array}{l}\text { Cultivated, } \\
1200\end{array}$ \\
\hline $\begin{array}{l}\text { A. tuberosum Rottler ex } \\
\text { Spreng. }\end{array}$ & $\begin{array}{l}n=8 I V-32 I \\
2 n=9,11,24,321983\end{array}$ & Roy (1980) & $\begin{array}{l}\text { Cultivated, } \\
1200\end{array}$ \\
\hline $\begin{array}{l}\text { A. tuberosum Rottler ex } \\
\text { Spreng. }\end{array}$ & $\begin{array}{l}n=8-10,8-14 \\
31,32 \text { (irr) etc } \\
2 n=31,32,33 \\
62\end{array}$ & Gohil \& Koul (1983) & $\begin{array}{l}\text { Cultivated, } \\
1200\end{array}$ \\
\hline $\begin{array}{l}\text { A. tuberosum Rottler ex } \\
\text { Spreng. }\end{array}$ & $n=16,2 n=32$ & Zou \& Jia (1985) & $\begin{array}{l}\text { Cultivated, } \\
1200\end{array}$ \\
\hline $\begin{array}{l}\text { A. tuberosum Rottler ex } \\
\text { Spreng. }\end{array}$ & $2 n=16,32$ & Yang et al. (1998) & $\begin{array}{l}\text { Cultivated, } \\
1200\end{array}$ \\
\hline $\begin{array}{l}\text { A. tuberosum Rottler ex } \\
\text { Spreng. }\end{array}$ & $2 n=31-33$ & $\begin{array}{l}\text { Mehra \& Pandita (1979), } \\
\text { Pandita (1981) }\end{array}$ & $\begin{array}{l}\text { Cultivated, } \\
1200\end{array}$ \\
\hline $\begin{array}{l}\text { A. tuberosum Rottler ex } \\
\text { Spreng. }\end{array}$ & $2 n=21-32$ & Gohil \& Koul (1978) & $\begin{array}{l}\text { Cultivated, } \\
1200\end{array}$ \\
\hline $\begin{array}{l}\text { A. tuberosum Rottler ex } \\
\text { Spreng. }\end{array}$ & $n=8,2 n=16$ & Pradhan (1980) & $\begin{array}{l}\text { Kuleswor, } \\
1250\end{array}$ \\
\hline $\begin{array}{l}\text { A. tuberosum Rottler ex } \\
\text { Spreng. }\end{array}$ & $2 n=32$ & $\begin{array}{l}\text { Saiju (1982), Adhikari } \\
\text { (1998), Manandhar et al. } \\
\text { (2011) }\end{array}$ & $\begin{array}{l}\text { Kuleswor, } \\
1250\end{array}$ \\
\hline $\begin{array}{l}\text { A. tuberosum Rottler ex } \\
\text { Spreng. }\end{array}$ & $2 n=48+3 B$ & Present report & $\begin{array}{l}\text { Kuleswor, } \\
1250\end{array}$ \\
\hline Artemisia indica Willd. & $2 n=34$ & Joshi \& Joshi (2001) & CE $300-2400$ \\
\hline A. indica Willd. & $2 n=32$ & Manandhar et al. (2011) & CE $300-2400$ \\
\hline A. indica Willd. & $2 n=18$ & Present report & Lalitpur, 1250 \\
\hline $\begin{array}{l}\text { Bacopa monnieri (L.) } \\
\text { Pennel }\end{array}$ & $2 n=68$ & $\begin{array}{l}\text { Chandran \& Bhavanandan } \\
\text { (1981) }\end{array}$ & WC, $700-900$ \\
\hline B. monnieri (L.) Pennel & $2 n=34$ & Present report & $\begin{array}{l}\text { Kuleswor, } \\
1250\end{array}$ \\
\hline
\end{tabular}




\begin{tabular}{|c|c|c|c|}
\hline $\begin{array}{l}\text { Bougainvillea glabra } \\
\text { Choisy }\end{array}$ & $2 n=28$ & Present report & Lalitpur, 1250 \\
\hline Carica papaya L. & $2 n=18$ & $\begin{array}{l}\text { Joshi \& Ranjekar (1982), } \\
\text { Chen (1993) }\end{array}$ & C. 500 \\
\hline C. papaya L. & $n=18$ & Fernández Casas (1981) & C. 500 \\
\hline C. papaya L. & $2 n=27$ & Present report & $\begin{array}{l}\text { Kuleswor, } \\
1250\end{array}$ \\
\hline Cicer arietinum $\mathrm{L}$. & $n=8$ & Kumar (1976) & $\begin{array}{l}\text { WCE, } \\
150-1300 . \\
\text { Botanical } \\
\text { Garden } \\
\text { (CDB), } \\
\text { Kirtipur, } 1300\end{array}$ \\
\hline C. arietinum $\mathrm{L}$. & $2 n=16$ & Fukuda (1984) & $\begin{array}{l}\text { Kathmandu } \\
\text { market, } 1250\end{array}$ \\
\hline C. arietinum $\mathrm{L}$. & $n=8,2 n=16$ & Sarbhoy \& Sinha (1978) & $\begin{array}{l}\text { WCE, 150- } \\
1300\end{array}$ \\
\hline C. arietinum $\mathrm{L}$. & $2 n=16$ & $\begin{array}{l}\text { Phadnis (1971), Farook \& } \\
\text { Nizam (1979), Astanova } \\
\text { (1981), Lavania \& Lavania } \\
\text { (1982, 1983), Sharma \& } \\
\text { Gupta (1982), Kutarekar } \\
\text { \& Wanjari (1983), Yeh et } \\
\text { al. (1986), Mukhopadhyay } \\
\text { (1986), Bairiganjan \& } \\
\text { Patnaik (1989), Yan et } \\
\text { al.(1989), Mannan et al. } \\
\text { (1991), Venora et al. (1995), } \\
\text { Nazarova (1997) }\end{array}$ & $\begin{array}{l}\text { WCE, 150- } \\
1300\end{array}$ \\
\hline C. arietinum $\mathrm{L}$. & $n=8$ & $\begin{array}{l}\text { Kabir \& Singh (1991), } \\
\text { Ahmad (1993), Jahan et } \\
\text { al. (1994), Ahmad \& Chen } \\
(2000)\end{array}$ & $\begin{array}{l}\text { WCE, 150- } \\
1300\end{array}$ \\
\hline C. arietinum $\mathrm{L}$ & $2 n=16$ & Present report & Lalitpur, 1250 \\
\hline
\end{tabular}


Vaidya and Manandhar: Chromosome Numbers of Some.

\begin{tabular}{|c|c|c|c|}
\hline Passiflora edulis Sims & $2 n=18$ & Guerra (1986) & E, $1300-1700$ \\
\hline P. edulis Sims & $2 n=18$ & Present report & Lalitpur, 1250 \\
\hline Pisum sativum $\mathrm{L}$. & $n=7,2 n=14$ & Kumar (1976) & $\begin{array}{l}\text { WCE, } \\
\text { 1200-4000 } \\
\text { Botanical } \\
\text { Garden } \\
\text { (CDB), } \\
\text { Kirtipur, } 1300\end{array}$ \\
\hline P. sativum $\mathrm{L}$. & $2 n=14$ & Shrestha (1979) & Kirtipur, 1300 \\
\hline P. sativum $\mathrm{L}$. & $2 n=14$ & $\begin{array}{l}\text { Lavania. \& Lavania (1982, } \\
\text { 1983), Rost (1982), } \\
\text { Sharma \& Gupta (1982), } \\
\text { Kodama \& Mitchell (1982), } \\
\text { Li \& Du (1984), Therman \& } \\
\text { Murashige (1984), Zhang } \\
\text { (1986) Yeh et al. (1986), } \\
\text { Mukhopadhyay (1986), Li } \\
\text { (1989), Kodama (1989), Kar } \\
\text { \& Sen (1991), Mannan et } \\
\text { al. (1991), Koul \& Nirmala } \\
\text { (1993), Nirmala \& Kaul } \\
\text { (1993), Zhang et al. (1993), } \\
\text { Baranyi \& Greilhuber (1995), } \\
\text { Zhang (1998). }\end{array}$ & $\begin{array}{l}\text { WCE, 1200- } \\
4000\end{array}$ \\
\hline P. sativum $\mathrm{L}$. & $2 n=14,21$ & Present report & Lalitpur, 1250 \\
\hline Vicia faba L. & $n=6,2 n=12$ & Kumar (1976) & $\begin{array}{l}\text { Godawari, } \\
\text { Lalitpur } 1360\end{array}$ \\
\hline V. faba L. & $n=6,7$ & Malakar (1978) & $\begin{array}{l}\text { Botanical } \\
\text { Garden } \\
\text { (CDB), } \\
\text { Kirtipur, } 1300\end{array}$ \\
\hline V. faba L. & $2 n=12$ & Fukuda (1984) & $\begin{array}{l}\text { Kathmandu, } \\
1250\end{array}$ \\
\hline V. faba L. & $n=6,2 n=12$ & $\begin{array}{l}\text { Bairiganjan \& Patnaik } \\
\text { (1989). }\end{array}$ & \\
\hline V. faba L. & $n=6$ & $\begin{array}{l}\text { Kesavacharyulu et al. } \\
\text { (1982), Jahan et al. (1994). }\end{array}$ & \\
\hline
\end{tabular}




\begin{tabular}{|c|c|c|c|}
\hline V. faba L. & $n=4,5,6,7$ & Wang \& Zheng (1985). & \\
\hline V. faba L. & $2 n=12$ & $\begin{array}{l}\text { Langer \& Koul (1982), } \\
\text { Rost (1982), Tanaka \& } \\
\text { Ohta (1982), Zhang et } \\
\text { al. (1982), Langer \& Koul } \\
\text { (1984), Zhang (1986), Yuan } \\
\text { (1986), Yeh et al. (1986), } \\
\text { Sato (1988), Li (1989), Chen } \\
\text { (1989), Rizzoni et al. (1989), } \\
\text { Matsuda \& Muramatsu } \\
\text { (1989), Schubert \& Rieger } \\
\text { (1990), Hizume (1992, } \\
\text { 1993), Unnikrishna Pillai } \\
\text { \& Verma (1992), Schifino- } \\
\text { Wittmann et al. (1994), Bisht } \\
\text { et al. (1998), Anis et al. } \\
\text { (1998), Zhang (1998), Kamel } \\
\text { (1999), Koul et al. (1999). }\end{array}$ & \\
\hline V. faba L. & $2 n=12$ & Present report & $\begin{array}{l}\text { Kuleswor, } \\
1250\end{array}$ \\
\hline
\end{tabular}

\section{ACKNOWLEDGMENTS}

This research article is the continuation of the previous project works by the second author that was sponsored by the University Grants Commission of Nepal. Present chromosome counts for the taxa by the authors were done in the Central Department of Botany, Kirtipur and in the Botany Department, Trichandra Multiple Campus, Kathmandu.

\section{REFERENCES}

ADHIKARI, B (1998) Study of karyomorphology and anatomy of Alium tuberosum Roxb., Lilium longiflorum L. and Theropogon pallidus (Kunth) Maxim. of Lily Family. M.Sc. dissertation, Central Department of Botany, Tribhuvan University, Kirtipur, Kathmanu, Nepal.

AHMAD, S (1993) Meiotic studies in two cultivars of Cicer arietinum L. after gamma irradiation. Cytologia 58: 61-65.

AHMAD, F; CHEN, Q (2000) Meiosis in Cicer L. species: the relationship between chiasma frequency and genomic length Cytologia 65: 161-166.

ANIS, M; SHIRAN, B; WANI, AA (1998) Genotoxic effect of aldrin and malathion on the root meristem of Vicia faba Journal of Cytology and Genetics 33(1): 35-42.

ASTANOVA, S B (1981) Chromosome numbers of Leguminosae of flora in Tajikistan. Dokl. Akad. Nauk Tadziksk. SSR 24: 61-63 (In Russian).

BAIRIGANJAN, G C; PATNAIK, S N (1989) Chromosomal evolution in Fabaceae. Cytologia 54: 51-64. 
BANERJEE, N (1980) Chromosome studies in somes species of Allium. Proc. Indian Sci. Congr. Assoc. (IV, A) 67: 35.

BARANYI, M; GREILHUBER, J (1995) Flow cytometric analysis of genome size variation in cultivated and wild Pisum sativum (Fabaceae) Plant Systematics and Evolution 194: 231-239.

BISHT, M S; KESAVACHARYULU, K; RAINA, S N (1998) Nucleolar chromosme variation and evolution in the genus Vicia Caryologia 51: 133-147.

CELARIER, R P (1956) Tertiery butyl alcohol dehydration of chromosome smears. Stain Techniques 31: 155.

CHANDRAN, R; BHAVANANDAN, K V (1981) In Chromosome number reports LXXII. Taxon 30: 698.

CHEN,/R-Y (1989) A further research of plant chromosome G-banding. In D. Hong, D (ed) Plant Chromosome Research pp. 187-193.

CHEN, R-Y (1993) (ed) Chromosome atlas of Chinese fruit trees and their close wild relatives Chromosome Atlas of Chinese Principal Economic Plants. 1.

COTA, J H; PHILBRICK, C T (1994) Chromosome number variation and polyploidy in the genus Echinocereus (Cactaceae). Amer. J. Bot. 81: 1054-1062.

DHAR, U (2002) Conservation implications of plant endemism in high altitude Himalaya. Current Science 82(2): $141-8$.

FAROOK, S A F; NIZAM, J (1979) Mutagenic sensitivity of base specific chemicals in chick-pea. Indian Journal of Botany 2: 12-16.

FEDOROV, AA (1969) Chromosome numbers of flowering plants. Science Press, V. L. Academy of Science of USSR, Komarov Botanical Institute, Russia (1969 edition).

FERNÁNDEZ CASAS, J (1981) Recuentos cromosomáticos de algunas angiospermas de Bolivia y Perú. Saussurea 12: 157-164.

FUKUDA, I (1984) The study of legumes in Nepal. Sci. Rep. Tokyo Womens Christian Univ. 793-810.

GOHIL, R N; KAUL, R (1978) Seed progeny studies in Alliums. I. Numerical variants in the progeny of tetraploid Allium tuberosum Rottl. ex Spreng. Beitr. Biol. Pflanzen 54: 304-309.

GOHIL, R N; KOUL, A K (1983) Seed progeny studies in Alliums. II. Male meiosis in the progeny plants of tetraploid Allium tuberosum Rottl. ex Spreng. Cytologia 48: 109-118.

GUERRA, M D S (1986) Citogenetica de Angiospermas coletadas en Pernambuco, I. Revista Brasil. Genét. 9: 21-40 (In Portuguese).

HARA, H; WILLIAMS, L H J (1979) An enumeration of the flowering plants of Nepal (Vol. 2). British Museum, London, UK.

HARA, H; CHATER, A O; WILLIAMS, L H J (1982) An enumeration of the flowering plants of Nepal (Vol. 3). British Museum, London, UK.

HIZUME, M (1992) Exact location of rRNA genes in Vicia faba chromosomes Cytologia 57: 471-475.

HIZUME, M (1993) Chromosomal localization of 5S rRNA genes in Vicia faba and Crepis capillaries Cytologia 58: 417-421.

HUANG, R F; WEI, R C; YAN, Y X (1985) Discovery of spontaneous triploid of Allium tuberosum. J. Wuhan Bot. Res. 3: 429-431.

JAHAN, B; VAHIDY, AA; ALI, S I (1994) Chromosome numbers in some taxa of Fabaceae mostly native 
to Pakistan Annals of the Missouri Botanical Garden 81: 792-799.

JOSHI, C P; RANJEKAR, P K (1982) Visualization and distribution of heterochromatin in interphase nuclei of several plant species as revealed by a new Giemsa banding technique. Cytologia 47: 471-480

JOSHI, K K; JOSHI, S D (2001) Genetic heritage of medicinal and aromatic plants of Nepal Himalayas. Buddha Academic Publishers and Distributers Pvt. Ltd, Kathmandu, Nepal.

KABIR, G; SINGH, R M (1991) Meiotic studies in two species of Cicer and their hybrids Cytologia 56: 577-585.

KAMEL, E A (1999) Karyological studies on some taxa of the genus Vicia L. (Fabaceae) Cytologia 64: 441-448.

KAR, K; SEN, S (1991) A comparative karyological study of root and embryo tissue of a few genera of Leguminosae. Cytologia 56: 403-408.

KARNA MALLICK, P; MANANDHAR, L; VAIDYA, B L (2010) Karyomorphological observations on some taxa of Asteraceae of Nepal. International Conference, Biodiversity, Livelihood and Climate Change in the Himalayas, 12-14 December 2010, Kathmandu, Nepal, Abstract.

KESAVACHARYULU, K; RAINA, S N; VERMA, R C (1982) Cytogenetics of Vicia I. Male meiotic system in twelve species. Cytologia 47: 511-523.

KODAMA, A; MITCHELL, J P (1982) A comparative karyological and cytophotometric study of normal and wounded stem tissue of the pea (Pisum sativum L.). Cytologia 47: 409-418.

KODAMA, A (1989) Karyotype analyses of chromosomes in eighteen species belonging to nine tribes in Leguminosae Bulletin of the Hiroshima Agricultural College 8: 691-706.

KOJIMA, A; HINATA, K; NODA, S (1991) An improvement of squash method for cytological study of female meiosis in Allium tuberosum, Liliaceae. CIS Chromosome Inform. Serv. 50: 5-7.

KOUL, M L H; NIRMALA, C (1993) Male sterility in pea II. Male sex specific dys-synapsis Cytologia 58 : 67-76.

KOUL, K K; RAINA, S N; PARIDA, A; BISHT, M S (1999) Sex differences in meiosis between Vicia faba L. and its close wild relatives Botanical Journal of the Linnean Society 129: 239-247.

KUMAR, N (1976) Cytological studies on Papilionaceae Tribe Viceae. M.Sc. dissertation, Central Department of Botany, Tribhuvan University, Kirtipur, Kathamndu, Nepal.

KUMAR, V; SUBRAMANIAM, B (1986) Chromosome atlas of flowering plants of the Indian subcontinent. Vol. I., New Delhi, India: Bot. Sur. Ind.

KUTAREKAR, D R; WANJARI, K B (1983) Karyomorphological studies in some of the varieties of Bengal gram (Cicer arietinum Linn.). Cytologia 48: 699-705.

LANGER, A; KOUL, A K (1982) Studies on nucleolus and nucleolar chromosomes in angiosperms V. Accessory secondary constrictions in Vicia faba L. Chromosome Information Service 32: 8-9.

LANGER, A; KOUL, A K (1984) A case of chromosome pairing in root tip cells of Vicia faba. Chromosome Information Service 37: 5-6.

LAVANIA, U C; LAVANIA, S (1982) Chromosome banding patterns in some Indian pulses. Ann. Bot. 49: 235-239.

LAVANIA, U C; LAVANIA, S (1983) Karyotype studies in Indian pulses. Genet. Agr. 37: 299-308.

LI, M -X; DU, M.-X (1984) A karyotypic study of Pisum Acta Genetica Sinica 11(3): 195-201. 
LI, R; LIU, L; WANG, X (1985) Karyotype analysis on the different cultivars of Allium tuberosum Rottle. Chin. Bull. Bot. 3(5): 43-46.

LI, R Q (1989) Studies on karyotypes of vegetables in China. Wuhan University Press, Wuhan, China.

MALAKAR, R (1978) Cytological studies of some leguminous plants. M.Sc. dissertation, Central Department of Botany, Tribhuvan University, Kirtipur, Nepal.

MANANDHAR, L; VAIDYAAND, B L; SINGH SUWAL, B M (2010) Contribution to a chromosome atlas of the Nepalese flora II. Bulletin of Pure \& Applied Sciences 29b(2): 97-112.

MANANDHAR, L; VAIDYA, B L; MALLICK, P K (2011) Contribution to a chromosome atlas of the Nepalese flora III. Bulletin of Pure \& Applied Sciences 30b(1-2): 1-24.

MANANDHAR, L (2012) Chromosomal diversity of the leguminous flora. Pleione 6(1): 168-185.

MANNAN, M A; KABIR, G; SHAHEEN, N N; AKHTER, F N (1991) Meiotic studies in seven pulse crops of Bangladesh Cytologia 56: 511-515.

MARKS, G E; DAVIES, D R (1979) The cytology of cotyledon cells and the induction of giant polytene chromosomes in Pisum sativum. Protoplasma 101: 73-80.

MATSUDA, T; MURAMATSU, M (1989) A technique for detection of sister chromatid exchanges in flowering plant, and spontaneous sister chromatid exchanges in Vicia faba. Science Reports of the Yokohama National University : Section II : Biological and Geological Sciences 36: 1-10

MEHRA, P N; PANDITA, T K (1979) In IOPB chromosome number reports LXIV. Taxon 28: 405.

MERCY KUTTY, V C; KUMAR, H (1983) Studies on induced tetraploids in four diverse cultivars of pea (Pisum sativum L.). Cytologia 48: 51-58.

MUKHOPADHYAY, S (1986) Intergeneric relationship between three genera of Leguminosae Journal of the Indian Botanical Society 65: 124-129.

NANUSCYAN, E R; POLYAKOV, V J (1989) The dependence between the DNA content, the thickness of mitotic chromosomes and the volume of pollen grains in some species of genus Allium L. Biol. Nauki (Alma-Ata) 8: 50-56.

NAZAROVA, E (1997) Mediterranean chromosome number reports 7(803-815). Flora Mediterranea 7 : 213-218.

NEPAL BIODIVERSITY STRATEGY (2002) His Majesty's Government of Nepal, Ministry of Forests and Soil Conservation, HMG, Nepal.

NIRMALA, C; KAUL, M L H (1993) Male sterility in pea IV. Meiotic absence, arrest, breakdown and continuation Cytologia 58: 247-255.

OHBA, H (1997) Flora of Nepal Project (Keynote Address). In International Seminar-cum-Workshop on Flora of Nepal (April15-16, 1997).

$\mathrm{OHI}, \mathrm{M}$ (1990) Studies on the factor of existence in Allium chinense guessed from elimination of the constitution of chromosomes. J. Fac. Agric. Shinshu Univ. 27: 49-90.

OHRI, D; PISTRICK, K (2001) Phenology and genome size variation in Allium L.a tight correlation?. PI. Biol. (Stuttgart) 3: 654-660.

PANDITA, T K V P N M (1981) Cytology of Alliums of Kashmir Himalayas, III. Male meiosis. Nucleus (Calcutta) 24: 147-151.

PHADNIS, B A (1971) Karyoptypic studies in varieties of Cicer arietinum L. Journal of Cytology and 
Genetics 5: 80-88.

PRADHAN, M (1980) Karyomorphological investigation on two varieties of Allium cepa and Allium tuberosum. M.Sc. dissertation, Central Department of Botany, Tribhuvan University, Kirtipur, Kathmandu, Nepal.

PRAJAPATI, N (2000) Karyomorphological study of some exotic horticulture plants of Kathmandu Valley. M.Sc. dissertation, Central Department of Botany, Tribhuvan University, Kirtipur, Kathmandu, Nepal.

PRESS, J R; SHRESTHA, K K; SUTTON, D A (2000) Annotated checklist of the flowering plants of Nepal. The Natural History Museum, London, UK.

RAJBHANDARI, K R (2002-2003) A List of new records of flowering plants of Nepal excluding Graminae and Orchidaceae. Nahson Bulletin 12-13: 22-29.

RAO, S R; PANDEY, R; CHANDEL, K P S (1992) Genetic stability studies in regenerated plants of Allium tuberosum Rottl. ex Spreng-a cytological approach. Cytologia 57: 339-347.

RIZZONI, M; TANZARELLA, C; GUSTAVINO, B; DEGRASSO,F; GUARINO, A; VILAGLIANO, E (1989) Indirect mitotic non-disjunction in Vicia faba and Chinese hamster cells Chromosoma 97: 339-346.

ROST, T (1982) Comparative sensitivity of plant root meristems to acute gamma irradiation according to stationary phase cell distribution and DNA content. Cytologia 47: 743-757.

ROY, S C (1980) Chromosomal variations in the callus tissues of Allium tuberosum and A. cepa. Protoplasma 102: $171-176$.

SAIJU, H K (1982) Cytology of the genus Allium section cepa and Rhizirideum J. Inst. Sc. Tech. 5: 31-36.

SAKYA, S R (1999) Cytogenetical studies in genus Primula L. and its allies of Nepal Himalayas, (A Research Report). Publ. Sakya, L S, Kathmandu, Nepal.

SAKYA, S R; PRAJAPATI, N; MANANDHAR, L (2001) Cytogenetical study of some exotic garden plants of Kathmandu Valley. Nepal J. of Science and Technology 3: 25-32.

SARBHOY, R K; SINHA, R P (1978) Cytogenetical studies in some pulse and bean -Dolichos, Vigna, Cicer, Pisum. Proceedings of the Indian Science Congress Association (III, C) 65: 109-110.

SATO/S (1988) Color differential staining of NOR-associated heterochromatic segments using acridine orange Stain Technology 63: 235-240.

SCHIFINO-WITTMANN, M T; LAU, A H; SIMIONI, C (1994) The genera Vicia and Lathyrus (Leguminosae) in Rio Grande do Sul (southern Brazil): cytogenetics of native, naturalized and exotic species. Revista Brasileira de Genética 17(3): 313-319.

SCHUBERT, I; RIEGER, R (1990) Alteration by centric fission of the diploid chromosome number in Vicia faba L. Genetica 81: 67-69.

SEO, B B (1977) Cytogenetic studies of some tetraploids in Allium. Korean J. Bot. 20: 71-76.

SHANG, Z Y; LI, R J; CUI, T C; XU, J M (1997) Studies on chromosomes of eight species of Allium from China. Acta Phytotax. Sin. 35(5): 434-444.

SHARMA, P C; GUPTA, P K (1982) Karyotypes in some pulse crops Nucleus 25: 181-185.

SHRESTHA, S D (1979) Comparative karyotype study on Pisum sativum and Pisum arvense. M.Sc. dissertation, Central Department of Botany, Tribhuvan University, Kirtipur, Kathmandu, Nepal.

TALUKDER, K; SEN, S (2000) Chromosome characteristics in some Allium spp. and assessment of their interrelationship. Nucleus (Calcutta) 43(1,2): 46-57. 
TANAKA, R; OHTA, S (1982) A method for differential staining of centromere regions of plant chromosomes Japanese Journal of Genetics 57: 65-73.

THERMAN, E; MURASHIGE, T (1984) Polytene chromosomes in cultured pea roots (Pisum, Fabaceae). Plant Systematics and Evolution 148: 25-33.

TORRELL, M; VALLES,J; GARCIA-JACAS, N; MOZAFFARIAN, V; GABRIELIAN, E (2001) New or rare chromosome counts in the genus Artemisia L. (Asteraceae, Anthemideae) from Armenia and Iran Bot. Jour. Linnean Soc. 135: 51-60.

UNNIKRISHNA PILLAI, P R; VERMA, R C (1992) A comparison of induced chromosomal aberrations in Vicia faba and Phlox drummondii glimpses of cytogenetics in India 3: 17-23.

VENORA, G; OCAMPO, B; SINGH, K B; SACCARDO, F (1995) Karyotype of the kabuli-type chickpea (Cicer arietinum L.) by image analysis system Caryologia 48(2): 147-155.

WAKABAYASHI, M (1988) Present situation of cytotaxonomy of Himalayan plants. Newslett. Himalayan Bot. 8-11.

WANG, X; ZHENG, G (1985) The relations between chromosome aberration and the intercellular chromatin migration in pollen mother cells of Vicia faba. Acta Botanica Sinica 27: 141-146.

XU, J X; LUO, D G; JIANG, M C (1985) Young leaves of Allium tuberosum are good materials for observing mitotic division. Guangxi Nongye Xueyuan Xuebao (J. Guangxi Agric. Coll.) (2): 24. (In Chinese).

YAN, G-X; ZHANG, S-Z; YAN, J-F; FU, X-Q; WANG, L-Y (1989) Chromosome numbers and geographical distribution of 68 species of forage plants. Grassland of China [Zhongguo caoyuan] 4: 53-60.

YAN, L; WANG, L Y; LI, H (1999) The chromosome number and karyotype analysis of 10 species of Allium from Neimongolia. Grassl. China 1999(5): 72-74.

YANG, L; XU, J M; ZHANG, X L; WAN, H Q (1998) Karyotypical studies of six species on the genus Allium. Acta Phytotax. Sin. 36(1): 36-46.

YEH, M S; YUASA, H; MAEKAWA, F (1986) Chromosome numbers in the Leguminosae. Sci. Rep. Res. Inst. Evol. Biol. 3: 57-71.

YUAN, S-A (1986) The new method of silver-staining in Vicia faba chromosomes. Hereditas (Beijing) 8: 16. ZHANG, Z; DONG, G; LU, P (1982) Study on the chromosome N-banding in plants Acta Botanica Sinica 24: $120-124$.

ZHANG, C-S (1986) Chromosome preparation with young plant cotyledon. Journal of Wuhan Botanical Research 4: 373-376.

ZHANG, Z-P; WU, L-H; KANG,Y-F (1993) Analyses of karyotypes in six forage grass species of Leguminosae. Botanical Research 1: 60-61.

ZHANG, C S (1998) A preliminary study on making plant chromosomal specimens using peppermint oil compound as pretreatment agent. J. Wuhan Bot. Res. 16(3): 280-282.

ZOU, D Q; JIA, Q Y (1985) Cytological study on chinese chive (Allium tuberosum Rottl. \& Spreng.) and wild chive (A. ramosus), Herbei Nongye Xuebao (J. Herbei Agric. Univ.) 8(1) :12-17. 